\title{
LAZAR HOUSES AND THE DISSEMINATION OF LEPROSY
}

Francis Blomefield, Rector of Fersfield in Norfolk wrote an elaborate description of his shire, An Essay Towards a Topographical History of the County of Norfolk . . . (the complete title-page goes to more than 150 words), which in its second edition, published in 1805-1810, occupies eleven volumes. This compilation contains some interesting bits of information about leprosy (italics in the original):

A LEPER-HOUSE [in Norwich] called St. STEPHEN'S HOSPITAL, which was formerly inhabited by lepers, lazars, and lame folks ... (Blomefield, vol. 4, p. 166).

In 1606, Edmund Newport had a grant of it in reversion, in which it is said to be then called the Spitel-house, and was inhabited by lepers, lazars, and lame folks . . . it seems Joshua Atkinson, glover, succeeded; for he, in 1629, as master and guider of the poor-house or hospital without St. Stephen's-gates, with the consent of the poor brothers and sisters therein inhabiting, for 5l. paid them by the officers of Fersfield in Norfolk, did admit into the society of the said house, Thomas Symonds, alias Cowper, a lame boy of 4 years of age, and a poor child of Fersfield aforesaid, there to be kept and maintained during life. . . .

These quotations show that in the middle ages and in early modern times "lame folks' were sometimes placed in confinement with lepers and that in at least one instance a disabled child was treated similarly. We now know that children are highly susceptible to leprosy. Hence if the practice of placing children and cripples in lazar houses was at all common, these establishments may have contributed to the increase of the disease.

SAUL JARCHO

\section{A NOTABLE PHARMACY COMES TO MELBOURNE}

The Department of Medical History, University of Melbourne, has been presented with the fittings and furniture of Savory \& Moore's pharmacy formerly of 29 Chapel Street, Belgrave Square, London. This generous gift from the Wellcome Trust had the enthusiastic support of Dr. F. N. L. Poynter, Director of the Wellcome Institute of the History of Medicine, who had opened the Department in 1967. The pharmacy has been re-erected in the Museum in its original form including a reduced facsimile of the bow window, and was officially opened by Sir Robert Menzies, the Chancellor of the University, on 1st June. The mahogany shelves, drawers and cupboards are in an opulent late-Regency style well proportioned to the narrow, but deep, shop making it a unique attraction probably unparalleled in Australia.

The pharmacy was opened in 1915 at 29 Chapel Street as one of the branches of Savory \& Moore's main shop in New Bond Street and was constructed in a converted portion of a Georgian terrace house. The ground floor of the house was gutted to obtain an area 45 feet long by 9 feet wide, the width being increased in front to 12 feet by including the hallway. A bow window was installed in front of which was the usual area, surrounded by elegant wrought iron railings, which led to a basement which could also be entered from the shop by means of a circular staircase behind the dispenser's bench. The mahogany fittings came from an earlier pharmacy dating from about $1860-70$ and were adapted to fit the new shop. The only clue to the date of the original fittings is a stamp of 'Oct. 1875' on the back of a mirror. On the back wall of the shop is a gold-lettered sign on a glass panel which proclaims 'Savory \& 
Moore, to the Queen, H.R.H. the Prince of Wales and the King of the Belgians and at 143 New Bond St.'

Until it closed in 1968 the shop supplied the needs of the fashionable inhabitants of Belgrave Square and of Buckingham Palace nearby; in the window was the notice of Warrant of Appointment to H.R.H. the Duke of Edinburgh with his coat-of-arms. When it closed Savory \& Moore presented the fittings to the Wellcome Institute of the History of Medicine.

The reconstructed shop has been developed as a museum exhibit to show the types of drugs available in the latter part of the last century when all medicines were compounded on the premises by the pharmacist and in this regard most of the bottles and jars came from Palmer's Pharmacy, Ballarat, most with their contents of the period 1870-1890; all these are strictly contemporary with those originally in the Chapel Street shop. In addition, the various pharmaceutical containers and equipment in use during the last century are shown; there is also a display of the goods sold by a period pharmacy such as feeding bottles, nipple shields, pap boats, measures, etc.; and finally there is a small display of pre-1920 drugs manufactured by Burroughs Wellcome and other firms.

Savory \& Moore was established in 1797 by Thomas Field Savory at 143 New Bond Street. Savory, a bachelor, was a well-known figure in the fashionable world of London at the time who entertained his friends at musical evenings held in his quarters above the shop; as well he was a shrewd businessman. The shop with its double bow window was designed by George Maddox and exists today in its original form although now incorporated in a new building which rises above the shop. In the 1860s the firm introduced the first of the artificial foods for babies.

Early association with the Royal Family resulted in their holding at various times

Warrants of Appointment as Chemist to Queen Victoria, King Edward VII, King George V, Queen Mary, King George VI, Queen Elizabeth the Queen Mother, Queen Elizabeth II, the Duke of Edinburgh, Princess Margaret, Princess Alexandra and the Duke of Windsor. Foreign royalty including the King of the Belgians and the Khedive of Egypt also patronized the firm, as did the Duke of Wellington, Miss Florence Nightingale, Lord Palmerston, Benjamin D'Israeli, Lord Salisbury and many other notables.

During the last forty years Savory \& Moore have amalgamated with John Bell \& Croyden, with Squires of Oxford Street, with William Martindale, and in 1967 merged with Macarthys Ltd.

This gift to the University of Melbourne is yet another example of the generosity of the Wellcome Trust who also provided the funds for the Department of Medical History in which the pharmacy is housed. The Wellcome Trust was created by the will of Sir Henry Wellcome who directed that the profits from Burroughs Wellcome \& Company should revert to a Trust and be used by the Trustees to advance medical research in any part of the world.

\section{REFERENCES}

Anonymous, 'Postwar enterprise comes of age', Suppl. to Chemist and Druggist, 18 November 1967. (Deals with Macarthys Ltd. and Savory and Moore).

- Savory \& Moore Ltd., Personal communication, 1971.

K. F. RUSSELL 


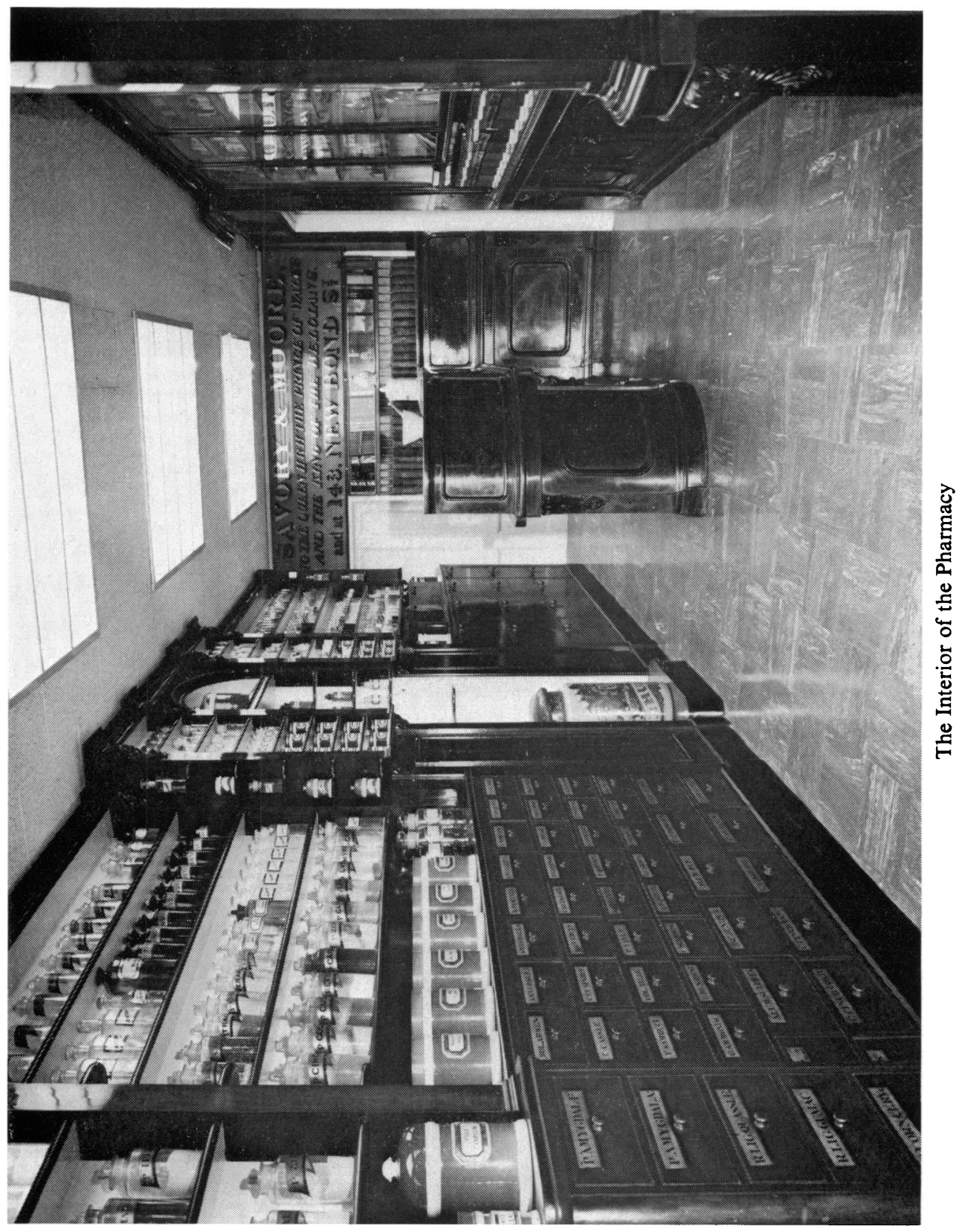




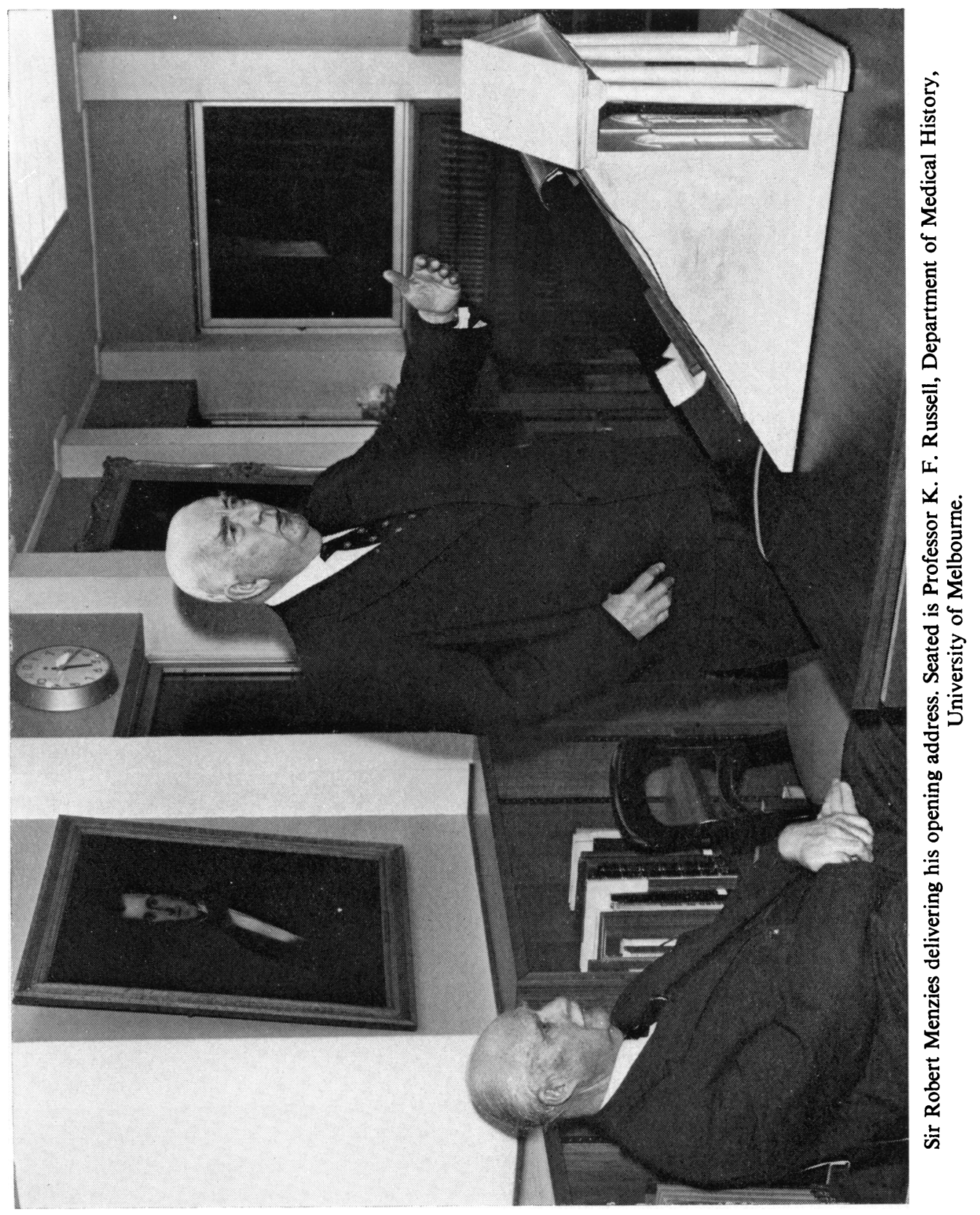

